\title{
THE OXYSTOMATOUS CRABS OF THE BARUNA EXPEDITION
}

\author{
Kasijan Romimohtarto *)
}

\section{INTISARI}

Dari hasil koleksi Brachyura dari Ekspedisi BARUNA, oxystomata merupakan golongan Jang paling sedikit dikumpulkan.

empatbelas species, diantaranja dua jang masih belum diketahui nama speciesnja, telah dipeladjari dan disusun dalam karangan ini.

Meskipun sedikit djumlah speciesnja tetapi ternjata banjak diantaranja jang perlu mendapat penelaahan jang lebih mendalam untuk menentukan kedudukan mereka jang tepat. dalam taksonomi.

\section{ABSTRACT}

Oxystomata constitutes the smallest number of species among the Brachyura collected during the BARUNA EXPEDITION.

Fourteen species, among which of two the idetification is doubtful, have been studied and included in this paper.

Though only few species recorded, many of them are to be more closely studied to ascertain their true position In taxonomy.

\section{INTRODUCTION}

The records on the crabs of the eastern Indonesian waters have been published by many authors such as DEMAN (1902), BALSS (1910), IHLE (1918), GORDON (1934) BUITENDIJK (1939) and others, after which no other new records on the crabs of this area have been published.

*) Biologist of the Inst. of Mar. Res. Pasar Ikan, Djakarta, Indonesia. 
Oxystomata represent only a small group in the collection, of which 12 species and 2 doubtful ones are described. Many of them are interesting and need a special study to ascertain their correct names.

The illustration of the first male pleopods is made in two ways, i.e. by drawing straight under the lens and by pressing and preparing them before being drawn.

Tribe OXYSTOMATA de Haan.

Family DORIPPIDAE Dana.

Genus Dorippe Fabricius.

Dorippe dorsipes (Linnaeus).

Dorippe dorsipes, Alcock,1896, p.277; Rathbun, 1911, p.197;, Ihle, 1918. p.148; Balss, 1922, p.119; Shen, 1931, p.98, text-figs 5 7, pl. 5 : figs 1 - 2.; Chopra, 1933, p.50; Sakai, 1937, p.73, pl, X, fig.4; Barnard, 1950, p.390, fig. 73, a - c.

Material : 1 ㅇ S.E. Coast of Komodo Isl, 28 - v - 1964; carapace 29,50 $\mathrm{mm}$ long and $22 \mathrm{~mm}$ wide.

Family CALAPPIDAE Dana,
Genus Calappa Fabricius.
Calappa hepatica. (Linnaeus).

Calappa hepatica, Alcock, 1896, p.142; de Man, 1902, p.687; Rathbun, 1911, p.197; Ihle,1918, p.183, fig.80; Gordon, 1934, p.73; Sakai, 1937, p.89; pl. XII, fig.2; Buitendijk, 1939, p.230; Barnard, 1950, p.348, fig.66, a-d; Forest \& Guinot, 1961, p.11, figs, $1 a, 1 b, 2$.

This species is the commonest among the oxysiomatous crabs collected by the Baruna Expedition. It is also the commonest species in the genus In Indonesia. 
Nineteen specimens were collected.

C.1. C.b.

MATERIAL: SEX Locality Date

\begin{tabular}{|c|c|c|c|c|}
\hline & $\begin{array}{l}\text { In } \\
\text { mm }\end{array}$ & $\begin{array}{l}\text { In } \\
\mathrm{mm}\end{array}$ & & \\
\hline क & 27 & 42 & Saubi Isl. & $13-v-1964$ \\
\hline $0^{x}$ & 18 & 28 & Sesiil Isl. & $16-v-1964$ \\
\hline 우 & 38 & 60 & $\begin{array}{l}\text { S.E. coast } \\
\text { Komodo Isl. }\end{array}$ & $28-v-1964$ \\
\hline $0^{x}$ & 32 & 54 & $\begin{array}{l}\text { S.E. coast } \\
\text { Komodo Isl. }\end{array}$ & " \\
\hline ㅇ & 32 & 51 & $\begin{array}{l}\text { S.E. coast } \\
\text { Komodo Isl. }\end{array}$ & " \\
\hline i & 33 & 52 & $\begin{array}{l}\text { S.E. coast } \\
\text { Komodo Isl. }\end{array}$ & $"$ \\
\hline $0^{x}$ & 17 & 25 & $\begin{array}{l}\text { W. coast } \\
\text { Djinatu Isl. }\end{array}$ & $31-v-1964$ \\
\hline $0^{x}$ & 24 & 35 & $\begin{array}{l}\text { W. coast } \\
\text { Djinatu Isl. }\end{array}$ & " \\
\hline 우 & 21 & 35 & $\begin{array}{l}\text { W. coast } \\
\text { Djinatu Isl. }\end{array}$ & $"$ \\
\hline$\sigma^{x}$ & 32 & 50 & Hoga Isl. & $6-v i-1964$ \\
\hline $0^{x}$ & 36 & 62 & Hoga Isl. & $"$ \\
\hline 운 & 40 & 61 & Hoga Isl. & $5-v i-1964$ \\
\hline$\sigma^{x}$ & 40 & 68 & $\begin{array}{l}\text { Oc.St. } 71: 04^{\circ} 52^{\prime} \\
00^{\prime \prime S}: 135^{\circ} 25^{\prime} 00^{\prime \prime} \mathrm{E}\end{array}$ & $28-v i-1964$ \\
\hline $0^{x}$ & 36 & 58 & $\begin{array}{l}\text { Oc.St. } 71: 04^{\circ} 52^{\prime} \\
00^{\prime \prime S}: 135^{\circ} 25^{\prime} 00^{\prime \prime} \mathrm{E}\end{array}$ & $"$ \\
\hline $0^{x}$ & 35 & 57 & $\begin{array}{l}\text { Oc.St. } 71: 04^{\circ} 52^{\prime} \\
00^{\prime \prime} \mathrm{S}: 135^{\circ} 25^{\prime} 00^{\prime \prime} \mathrm{E}\end{array}$ & $"$ \\
\hline
\end{tabular}




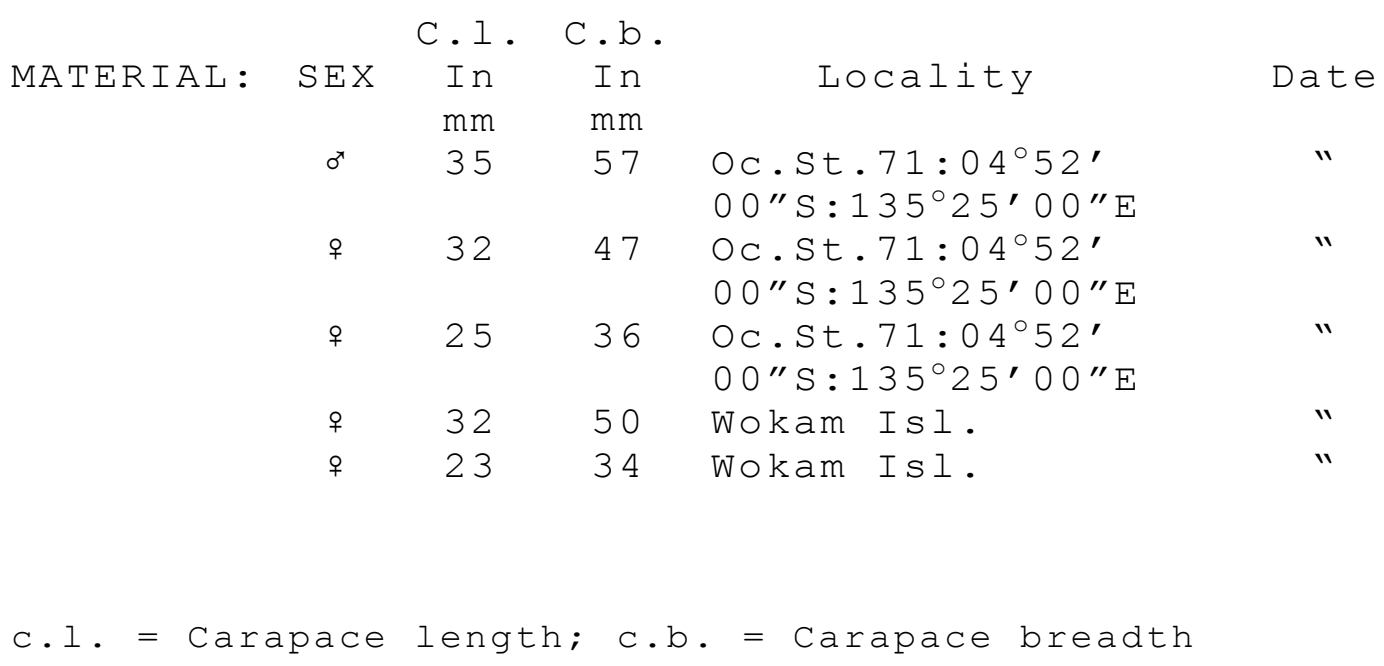

\section{Genus Matuta Fabricius,}

Matuta is the common genus of the oxystomatous crabs in Indonesian waters, especially In the bottom fisheries regions. The segregation of the genus is still unsatisfactory and unanimous.

MIERS (1876), uses the sculpture of the hand and finger and the coloration of the carapace to separate Matuta into nine species whereas ALCOCK (1896) recognizes only three species, I am of course not in the position to decide, since our material is very insufficient.

Two good species and two more doubtful ones are recorded in the collection studied.

\section{Matuta banksii Leach \\ ( Figure la and $2 a$ )}

Matuta banksii, Miers, 1876, p.245, pl.40, figs.1, 2 and 1880, p.315; de Man, 1888, $\mathrm{p}, 389$;

Alcock, 1896, p.158; Ihle, 1918, p.185;Balss, 1922, p.125; Gordon, 1934,p.73; Sakai, 1937, p.98, pl.13, fig.2; Buitendijk, 1939, p.231; Barnard, 1950, p.359, fig.67, h - k. 
Matuta picta, Miers, 1876, p.246, pl.40, fig. 5-7; de Man, 1902, p.685.

Matuta obtusifrons, Miers, 1876, p.247, pl.40, figs.8, 9.

First male pleopods are drawn for comparison.

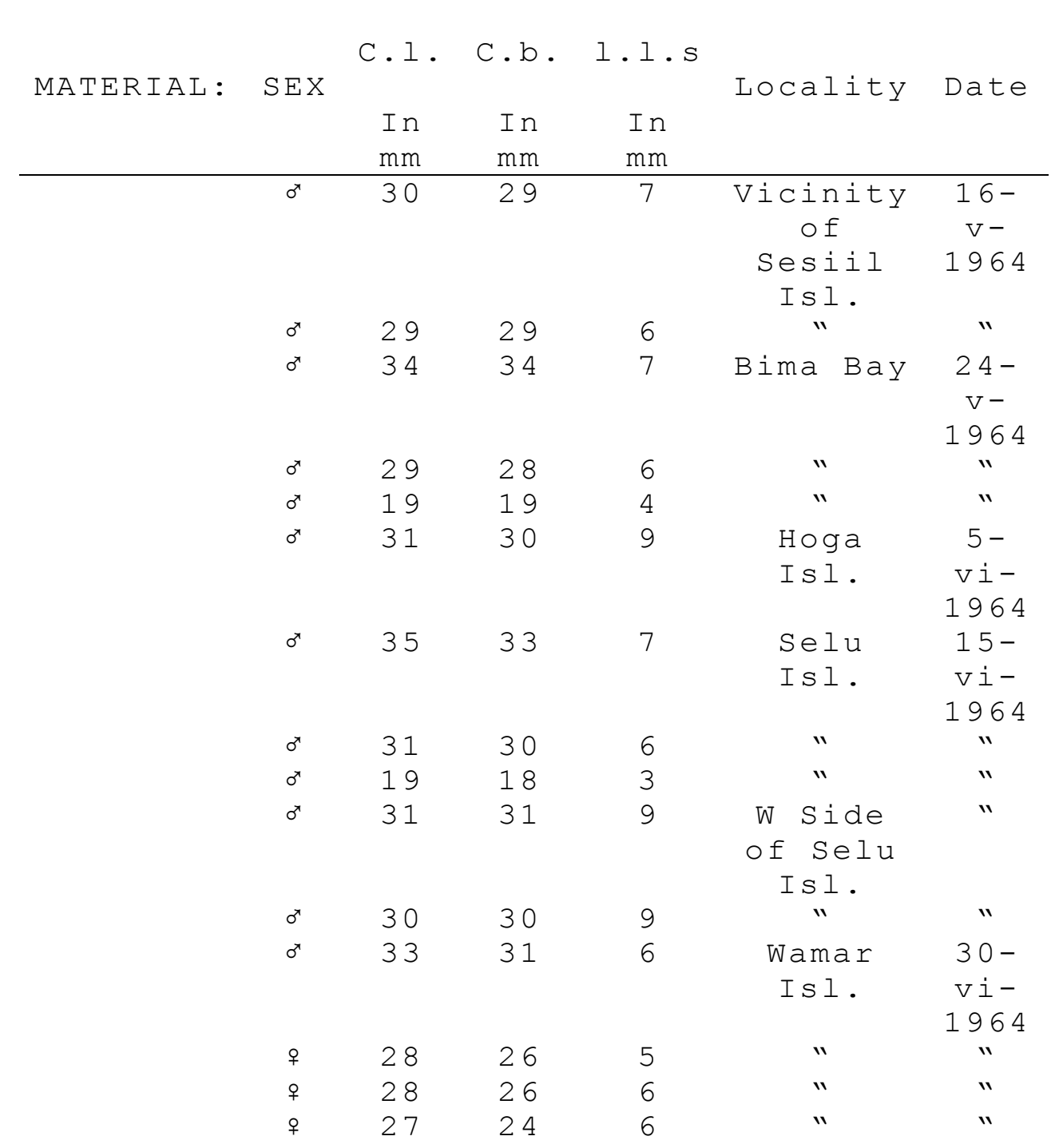




\begin{tabular}{|c|c|c|c|c|c|c|}
\hline \multirow{6}{*}{ MATERIAL: } & & C.I & C.b. & $1.1 . \mathrm{s}$ & & \\
\hline & SEX & In & $\begin{array}{l}\text { In } \\
\text { mm }\end{array}$ & $\begin{array}{l}\text { In } \\
\mathrm{mm}\end{array}$ & Locality & Date \\
\hline & $0^{x}$ & 25 & 23 & 5 & $"$ & $"$ \\
\hline & $0^{x}$ & 24 & 22 & 5 & " & " \\
\hline & $0^{x}$ & 24 & 22 & 6 & $"$ & $"$ \\
\hline & 오 & 27 & 25 & 5 & " & $"$ \\
\hline
\end{tabular}

Note : l.l.s. = Length of lateral spine

2. Matuta Iunaris (Forskal)

(Figures $1 \mathrm{~b}$ and 2b)

Matuta maculata, Miers, 1876, p.246, pl.40, figs,3 4,

Matuta victor, Alcock, 1896, p.160.

Matuta Iunaris, Stebbing, 1908, p.54; Ihle, 1918,p.185;

Balss, 1922, p.124; Sakai,1937, p.100, pl.XIII, fig.3; Buitendijk, 1939, p,231; Barnard, 1950, p, 358, fig.67, 1.

First male pleopod is drawn for comparison.

Material : $0,36 \mathrm{~mm}$ long, $34 \mathrm{~mm}$ broad, $7 \mathrm{~mm}$ of lateral spine length; Sesiil Isl. 16 - v - 1964,

\section{Matuta spp.}

As no litterature is available, identification was not feasable. It is certain, however, that our specimens are rare ones and may have never been recorded before for Indonesia. 
a. Matuta sp. I. (Plate I, A, B, C, and D)

The carapace is profusely granular on the branchial regions and along the regions parallel to the anterolateral borders, less so proximally. The six tubercles are distinct, the one on the cardiac region is the most distinct. There are additional tubercles, each on the branchial region close to where usually the postero-lateral eminence is formed,

This tubercles are very minute but distinc on the male, and are very distinct on our small female.

The antero-lateral borders are minutely crenulate. The last three crenulations form three distinct teeth. The posterior and postero-literal borders form a continuous granular slightly elevated ridge which stops at the place where the aminence Is usually formed.

The lateral spine is rudimentary. The front is distinctly wirier than the orbit and distinctly bilobed.

Hand with the upper border trilobed, the proximal one being the largest. The lower border dentate as far as the base of the Immobile finger Below the crest, on the upper side of the hand there are two rows of granules. The upper row is irregular and the lower one is regular, consisting of 5 teeth or granules. Below this there is a strongly milled ridge extending from the proximal end to the middle of the base of the mobile finger. In the small female specimen this ridge is formed by 5 united teeth, the second from the proximal end being the largest. Below this two rows of molariform tubercles cover the rest of the outer surface to the lower border.

The carpus of the pinultimate legs are full and single-carinate.

The rudimentary lateral spine seems to connect this species with M.enermis Miers as mentioned by ALCOCK (1896) in his key of Matuta.

The first male pleopod (figures Id and $2 \mathrm{~d}$ ) is similar in its cluster of heirs to that of $M$. Iunaris but differs considerably in form from that species.

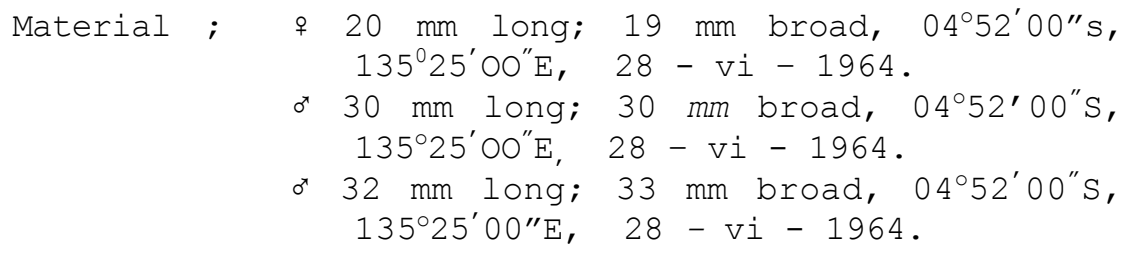



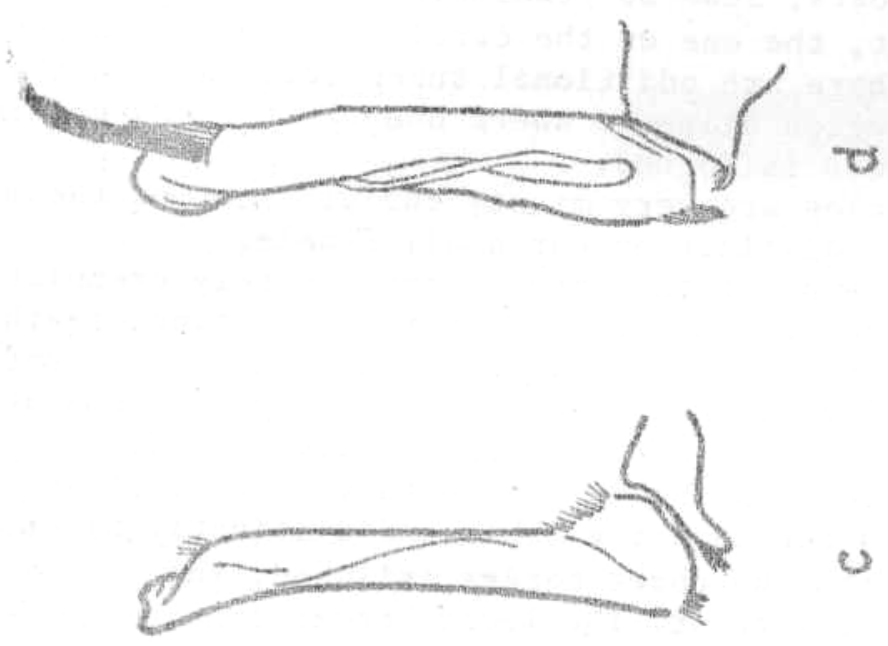

a) केष क्षे

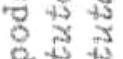

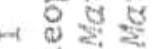

造:

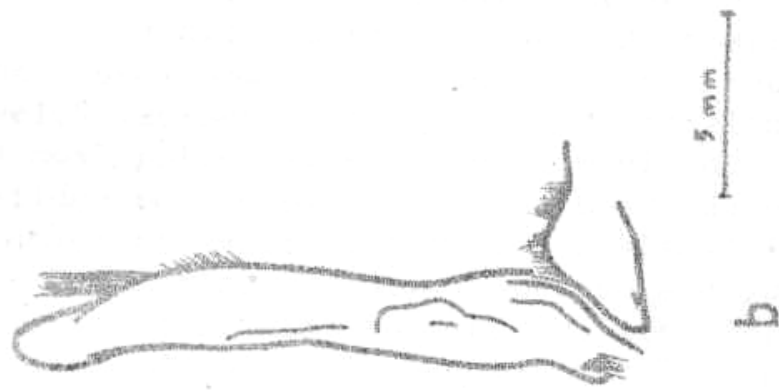

(4) 0 ,

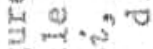

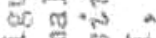

Fis a

t 80

मे का

4. 88

$2 \pi \frac{+3}{4}$

00,5

-1 2

o के

E.

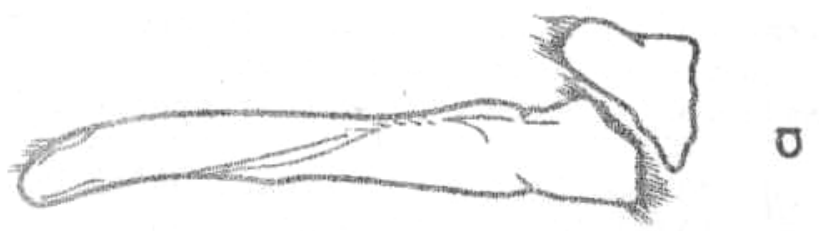


b. Matuta sp. II. (Plate I, E and F).

The collection of this second doubtful species consists mostly of small specimens. The carapace is minutely pitted. Six transverse tubercles distinct. Anterolateral border crenulate. The crenulation gradually smaller towards the outer orbital angle. The posterior and postera-lateral border form a continuous, beaded, strongly elevated ridge, which runs almost to the tip of the small epibranchial spine. No trace of tubercles or eminence on portero-lateral border, The length of the epibranchial spine Is about $1 / 9$ the breadth of the carapace.

Front Is wider than the orbit, The rostrum is distinctly bilobed, the lobes being triangular.

Hand with the upper border trilobed The proximal one being the largest. The other two are equal. The edges of the lobes densely hairy. Lower border dentate as far as the base of the immobile finger. Below the crest there are two rows of teeth. The upper row of 5 teeth is broken or interrupted. The lower one also consists of 5 teeth. Below this the hand is traversed by a longitudinal row of 4 tubercles continuing in a milled ridge as far as the cleft of the finger. Below these rows there are two longitudinal rows of tubercles, continuing as a ridge along the lower portion of the immobile finger. None of the tubercles are acute.

The lower edge of the hand forms a broad rounded tooth near to the base of the immobile finger. The carpus of the penultimate pair of legs is full, one carinate, no trace of second dorsal carina. The first male pleopod has a peculiar form, especially the distal portion, which is very concave and densely filled with long hairs. The concavity is toward the lower surface.

\begin{tabular}{|c|c|c|c|c|c|c|}
\hline Material & Sex & $\begin{array}{c}\text { c.l. } \\
\text { In mm }\end{array}$ & $\begin{array}{c}\text { c.b. } \\
\text { In mm }\end{array}$ & $\begin{array}{c}\text { 1.s.1 } \\
\text { In mm }\end{array}$ & Locality & Date \\
\hline & $\begin{array}{l}q(\text { ov }) \\
+ \\
+ \\
0 \\
0\end{array}$ & $\begin{array}{c}18 \\
13.5 \\
19\end{array}$ & $\begin{array}{c}18.5 \\
14 \\
19.5\end{array}$ & $\begin{array}{l}2 \\
1 \\
2\end{array}$ & & \\
\hline
\end{tabular}




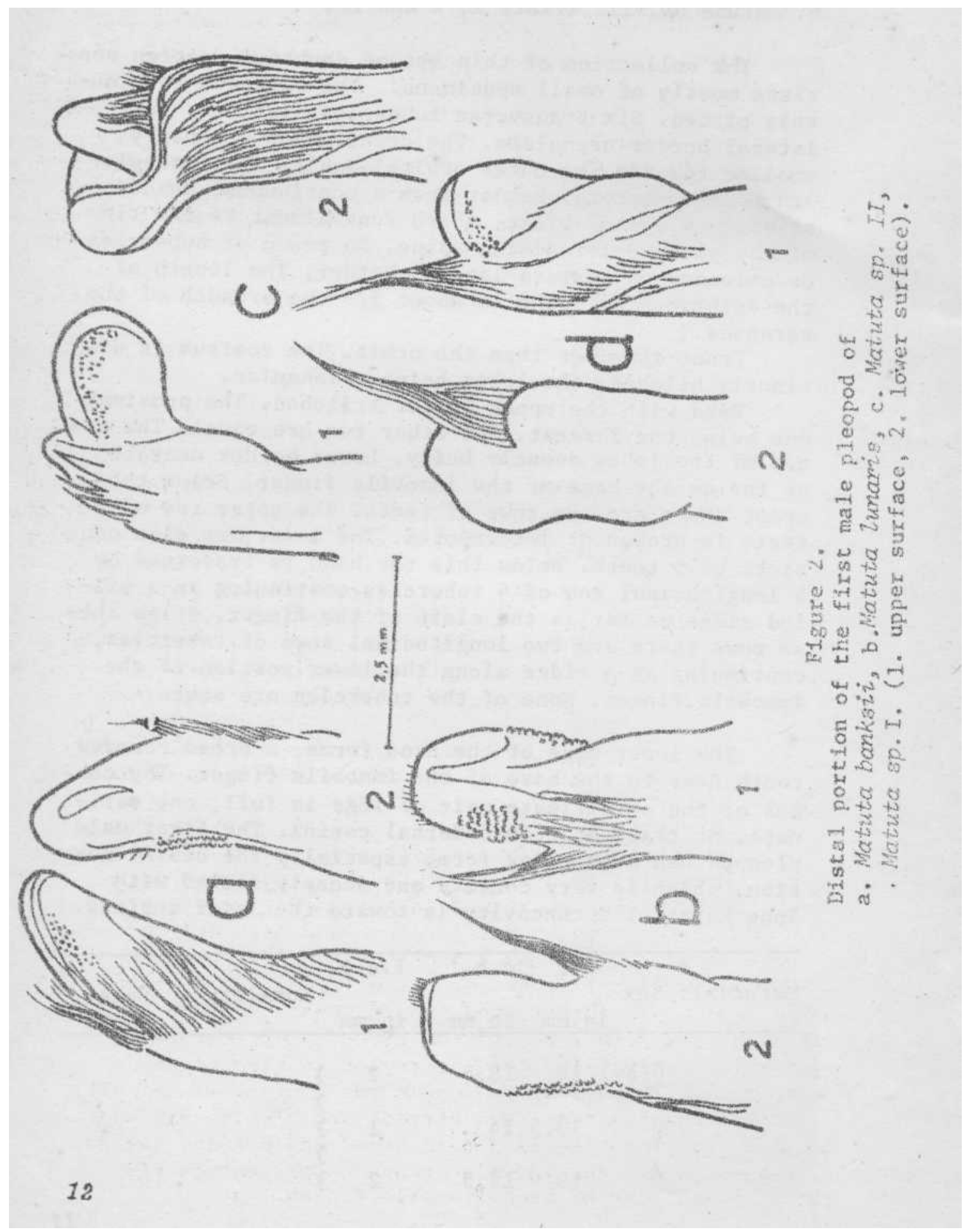




\begin{tabular}{|c|c|c|c|c|c|c|}
\hline Material & Sex & $\begin{array}{c}\text { c.l. } \\
\text { In mm }\end{array}$ & $\begin{array}{c}\text { c.b. } \\
\text { In mm }\end{array}$ & $\begin{array}{c}1 . s .1 \\
\text { In mm }\end{array}$ & Locality & Date \\
\hline & $\begin{array}{l}\hat{0} \\
0 \\
+ \\
\hat{0} \\
\hat{0}\end{array}$ & $\begin{array}{l}13 \\
13 \\
20 \\
23\end{array}$ & $\begin{array}{c}14.5 \\
13.5 \\
21 \\
24\end{array}$ & $\begin{array}{c}1.5 \\
1.5 \\
2 \\
2.5\end{array}$ & $\begin{array}{c}04^{\circ} 52^{\prime} 00^{\prime \prime} \mathrm{S} \\
135 \mathrm{o} 25^{\prime} 00^{\prime} \mathrm{E} \\
70 \text { m deep }\end{array}$ & 28-vi-1964 \\
\hline
\end{tabular}

Family LEUCOSIIDAE Dana. Genus Oreophorus Ruppell Subgenus Oreophorus Ruppell

Oreophorus (Oreophorus) rugosus Stimpson. (Plate II figure A).

Oreophorus (Oreophorus) rugosus, Ihle, 1918, p.212, fig. 121: Sakai, 1937, p.117; Serene, 1954, p. p.468, fig.3:2, 3, 4 and fig.4: $a, b, p l .8$

Carapace transversely subelliptical, broader than long, the length-width proportion being $1: 1.33$. The upper surface is rugose and eroded, covered with mushroom like granules appearing to the naked eye as the surface of rough rocky coral. Along and parallel to the anterolateral border is a broken and eroded groove. Along and parallel to the postero-lateral border is a more broken and interrupted groove separating the cardiac and intestinal regions on either side from the branchial region. The cardiac region is strongly convex, but the branchial region is the most convex of all.

The chelipeds are symmetrical and also tugosa and eroded. The immobile finger is broad and bending inward. A line of close-set and flat granules present on the inner lower edge of each immobile finger. 
The dactylus is slender and curved. The ambulatory less have a coarse surface, similar to that of the others.

The female abdominal formula is $2+3+\mathrm{R}+\mathrm{T}$. The first segment being concealed. There are two rows of interrupted shallow grooves along the middle line continuing into lateral edges of the last abdominal segment.

IHLE (1918) has given a detailed description of the adult specimen of this species in comparison with the young one.

SERENE's excellent figure (1954, fig, $3: 4, \mathrm{p} .472$ ) is identical with our specimen.

Material : o $9 \mathrm{~mm}$ long; $12 \mathrm{~mm}$ broad, North-West coast of Larat Island, 22 - vi - 1964.

Genus Arcania Leach.

1. Arcania undecimpinosa de Haan

(Plate II figure B ).

Arcania undecimspinosa, Bell, 1855, p.309; Alcock,1896, p.266; Balss, 1922, p.132; Shen, 1931, p.107, pl.10, fig. 1; Sakai, 1937, p.133, pl.XIV, fig.2.

Carapace distinctly longer than broad. Surface evenly and distinctly granulated, the granules sharpish. Eleven spines present on various parts of the body, arranged as follows: one on each pterygostomian region, three on each branchial margin, two on the posterior margin and one on the intestinal region. The anterior spine on the branchial margin is the smallest of all.

Front with two spinous lobes.

In many cases the description of ALCOCK (1896) agrees with the specimen. The granules extend to the spines and the most anterior spines arc not the smallest of all.

In some points (carapace measurement and first male pleopod) the specimens agree with Arcania undecimspinosa var. elongata Yokoya, but in other points they agree more with $A$. undecimspinosa (figure.3,) 
The inclogion of our specimens into var. Elongata needs confirmation.

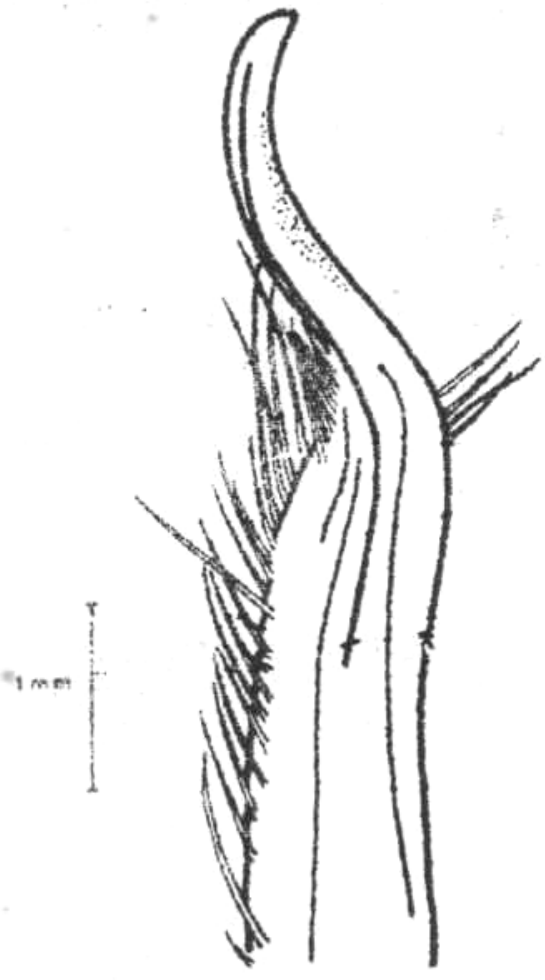

a

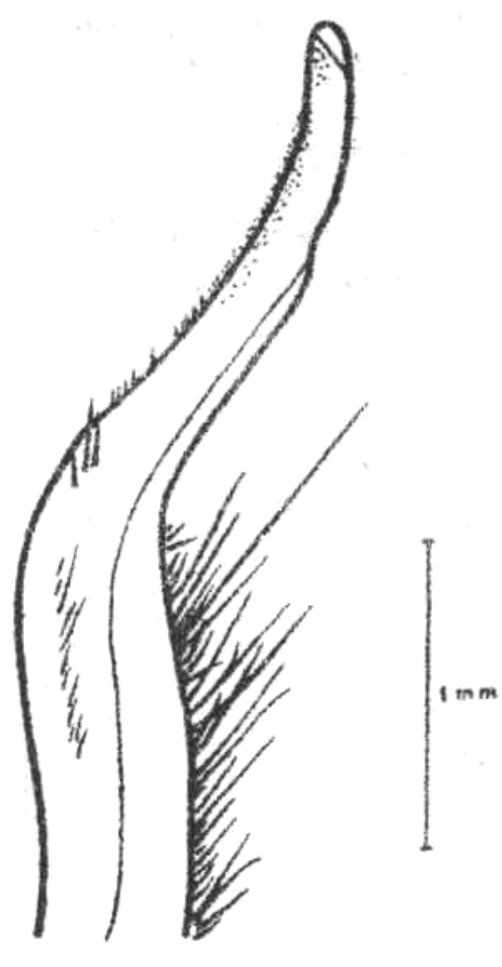

b

Figure 3.

The first male pleopod of $A$. undecemspinosa as compared to that of $A$ undecemspinosa var. elongata of Sakai (1937).

Material : $2{0^{x} 0^{x}}^{2} 1 \mathrm{~mm}$ long; $19 \mathrm{~mm}$ broad, 04052'00"S; $135025^{\prime} \mathrm{OO} " \mathrm{E}$ at a depth of $70 \mathrm{~m} ., 28-$ vi-1964. $19 \mathrm{~mm}$ long; $15 \mathrm{~mm}$ broad, O4 52'00"S; 135025'00"E at a depth of 70 irwi $28-v i-1964$.

$$
\begin{gathered}
\text { 3. Arcania erinaceus } \\
\text { (Fabricus) } \\
\text { ( Plate II figure C). }
\end{gathered}
$$

Arcania erinaceus, Bell, 1855, p.309; Alcock, 1896, p, 268; Balss, 1922, p.133; Chopra, 1933, p.44; Sakai, p.126.

Two specimens are damaged due to mishandling, for- 
tunately after being identified and photographed.

Material : 2 of unmeasured, $04^{\circ} 52^{\prime} 00^{\prime \prime S} ; 135^{\circ} 25^{\prime} 00^{\prime \prime} \mathrm{E}$ at 70 m deep, 28 - vi - 1964.

Genus Pandalia Stimpson.

Randalia eburnea Alcock.

Randalid eburnea, Alcock, 1896; p.197; Ihle, 1918, p.246; Sakai, 1937, p.132, fig.22,

Two full-grown male specimens agree completely with the description of SAKAI (1937). The length of the chelipeds being: more than three times as long as the carapace as stated by the original author.

One of the specimens has the distal part of the exopodite of the external maxillipeds pubescent.

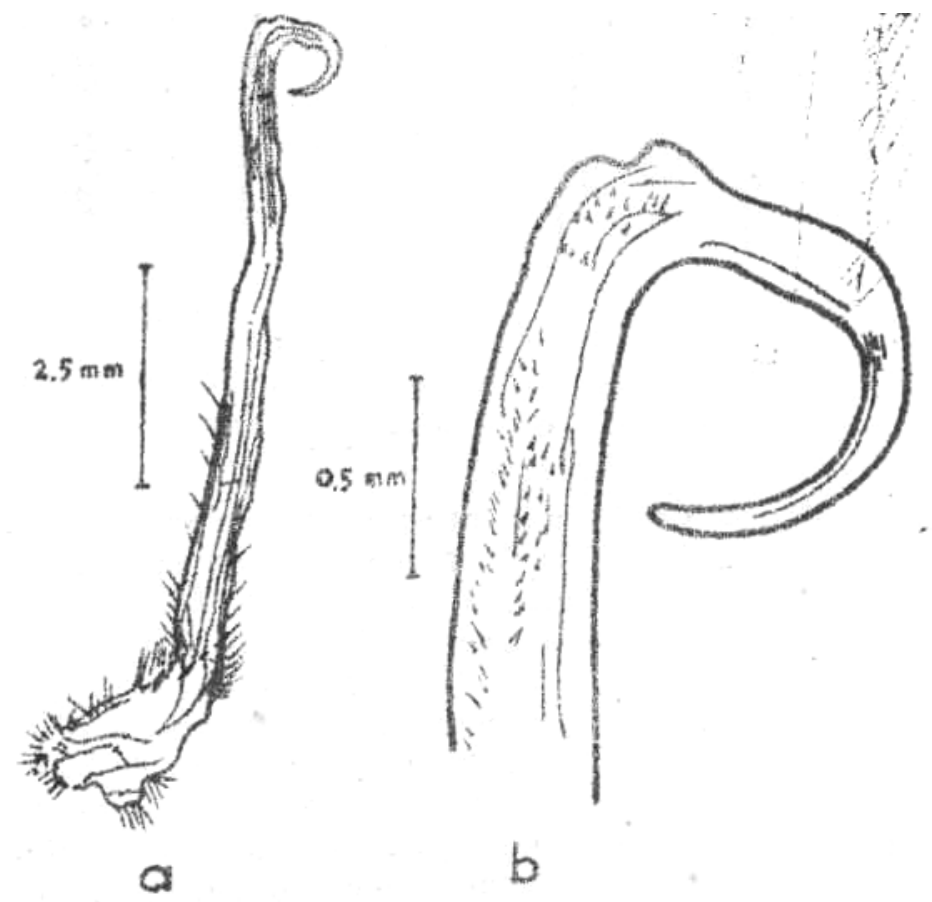

Figure 4.

The first male pleopod of Randalia eburnea Alcock.

a. left pleopod, b. distal portion. 
The first male pleopod of this species has a specific form. The distal portion being markedly bent and hooked ( fig. 4 ).

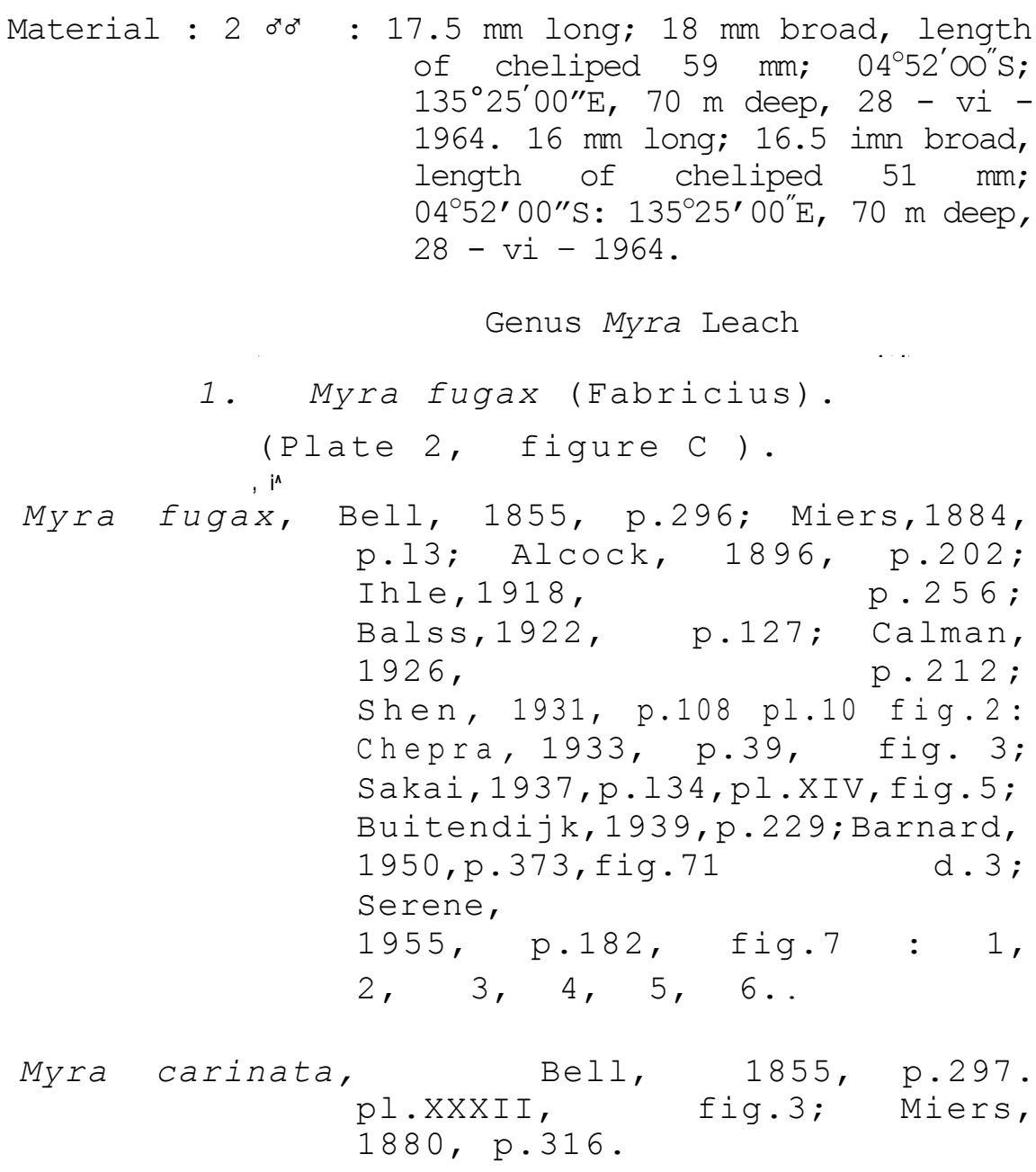

Myra punctata, de Man, 1888, p.205.

Myra penthacantha, Alcock, 1896, p.204; Serene, 1955,p.189, fig.7:4, 5; pl.10, fig, 2

Persephona fugax, Rathbun, 1911, p.201; Laurie, 1915

$$
\text { p. } 428 .
$$

Among the specimens examined there are two which are included into young Myra fugax. Those specimens conform with Alcock's (1896) description of $W$. penthacantha. Though he identified his specimens as young Myra fugax, but SERENE (1955) keeps his specimens as a separate species under Myra penthacantha. 
Compared to SERENE's figure (fig. 7 : 5, p. 191) we consider that our specimens belong to young Myra penthacantha. But the first male pleopods of all the specimens examined do not conform with our consideration. Enough material is needed to confirm the position of the species.

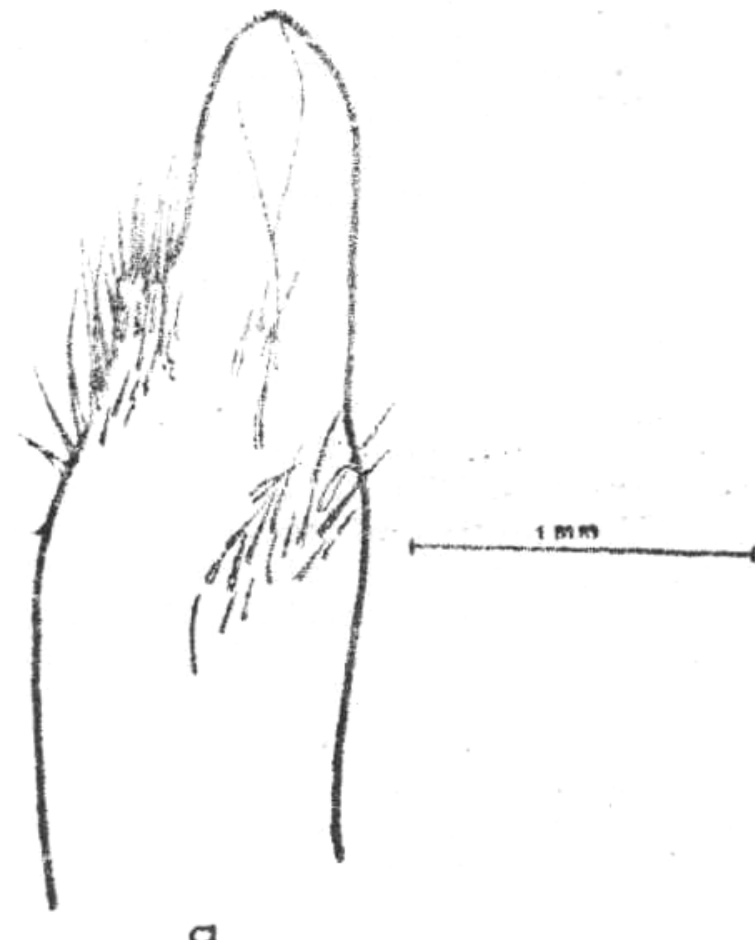

Figure 5 .

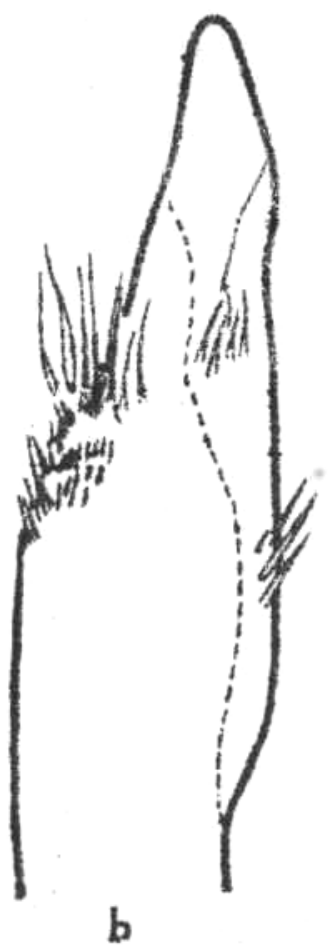

b

The first male pleopods of Myra fugax Leach and their distal portions; a.adult, b.young.

Fringes of heirs along the Inner part of the opposed adges of the external maxillipeds are present in our specimens, as was the case with the specimens of IHLE (1918), CHOPRA (1933) and BUITENDIJK (1939).

Material : $0^{x}: 23 \mathrm{~mm}$ long, $18 \mathrm{~mm}$ broad; 04 $52^{\prime} 00^{\prime \prime} \mathrm{S}$, $135^{\circ} 25^{\prime} 00^{\prime \prime} \mathrm{E}, 70 \mathrm{~m}$ deep, 28 - vi - 1964 .

$16 \mathrm{~mm}$ long, $15 \mathrm{~mm}$ broad; 0452'00"S; 
$135^{\circ} 25^{\prime} 00$ '"E, $70 \mathrm{~m}$ deep, 28 - vi - 1964.

$15 \mathrm{~mm}$ long, $14 \mathrm{~mm}$ broad; 0452'00"s; $135^{\circ} 25^{\prime} 00^{\prime}$ 'E, $70 \mathrm{~m}$ deep, 28 - vi - 1964.

$19 \mathrm{~mm}$ long, $16 \mathrm{~mm}$ broad; 04 $522^{\circ} 00^{\prime \prime S}$; $135^{\circ} 25^{\prime} 00^{\prime \prime E}, \quad 70 \mathrm{~m}$ deep, 28 - vi - 1964.

q : $21 \mathrm{~mm}$ long, $18 \mathrm{~mm}$ broad; 045' $00^{\prime \prime} \mathrm{S}$; $135^{\circ} 25^{\prime} 00^{\prime \prime} \mathrm{E}, 70 \mathrm{~m}$ deep, 28 - vi - 1964.

$21 \mathrm{~mm}$ long, $17 \mathrm{~mm}$ broad ; 0452'00”s; $135^{\circ} 25^{\prime} 00^{\prime \prime} \mathrm{E}, 70 \mathrm{~m}$ deep, 28 -vi- 1964

$19 \mathrm{~mm}$ long, $15 \mathrm{~mm}$ broad ; 0452'00”s; $135^{\mathrm{\prime}} 25^{\mathrm{f}} 00^{\mathrm{N}} \mathrm{E}, 70 \mathrm{~m}$ deep 28 - vi - 1964

$17 \mathrm{~mm}$ long, $15 \mathrm{~mm}$ broad; 05 49'30"S; $137^{\circ} 07^{\prime} 30^{\prime \prime} \mathrm{E}, 47.5 \mathrm{~m}$ deep, 28 - vi - 1964.(young).

\section{Myra kessleri (Paulson),} (plate 2 figure D).

Myva darnleyensis, Alcock, 1896 p.207.

Persephona darnleyensis, Rathbun, 1911, p.201.

Myra kessleri, Ihle, 1918, p.260, fig,139: Buitendijk, .1939, p,228; Serene, 1955, p.192,fig.8, pls, 10: 3 and $11: 1,2,3,4$,

Ihle (1918) describes (a large and full-grown female specimen, $17 \mathrm{~mm}$ long, without median spine) the three lobes of the posterior border as follows:

" Jeder seitliche Fortsatz am hinteren Rand 1st stumpfwinklig mit abgerundeter Spitze. Der mediane Fortsatz (zur intestinal Region gehorend) ist schmaler als die seitlichen Fortsatze und ungefahr rechtwinklig mit kaum abgerundeter Spitz".

lie further says for his young specimens, that: the form of the bind lobes rather differs from the description of $M$ darnleyensis. The side lobes of the female specimen from station 313 examined by IHLE (1918) are 
Half-cruciform, while the median remains short but more: spine-like. He places the specimen as Intermediate form between var. acutidens (the specimen from station 260) and the typical form. Our single female specimen does not conform with Ihle's material, but It conforms with the description of ALCOCK (1896), like the two specimens of SERENE (1955),

The three petaloid lobes of the posterior border are almost in the same level (fig.6).

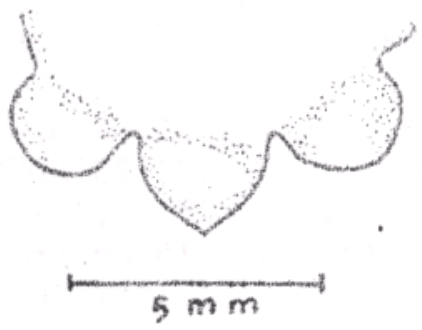

Figure 6. Hind lobes of M. kessleri ( Paulson).

They are flat, semicircular of feebly triangular. The median lobe is a little larger and more triangular than the two side lobes.

Material : $+20 \mathrm{~mm}$ broad, $19 \mathrm{~mm}$ long without median lobe; 04 52'00"S, 135²5'00"E; $70 \mathrm{~m}$ deep, 28 vi - 1964 .

Genus Ixoides McGilchrist,

Ixodes cornutus McGilchrist

( Plate 3, figure A).

Ixoides cornutus, Ihle, 1918, p.314 (list only); Gordon, 1931, p.530, fig.7; Sakai, 1937, p.137, pl.XIX, figs, 1-4.

It conforms with the description of SAKAI (1937) except that the exognath of our specimen is not very small, but rather moderately sixed. 
The tubercle on the middle of the convex intestinal region is very prominent.

The length of the lateral spines is more than $1 / 4$ the breadth of the carapace, they are patent and taper into acute points.

The granulations, except those described by SAKAI (1937), are present on the distal border of the frontal, lobes, on the border of the outer wall of the branchial channels and on the base of the lateral spines; the granules are close-set.

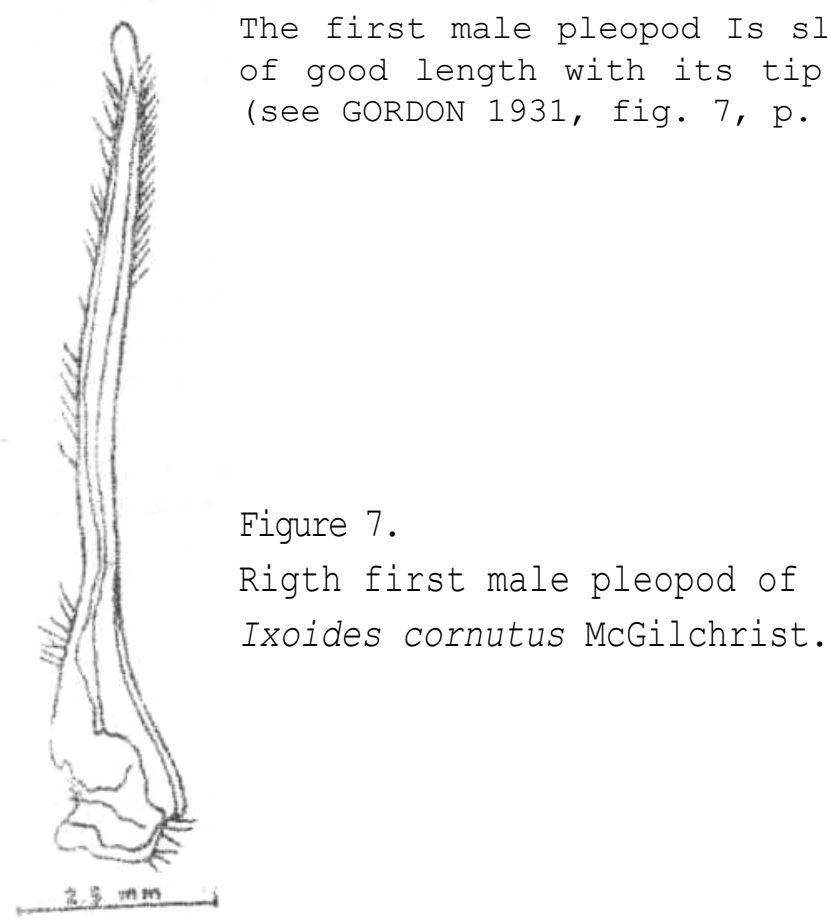

Material ': ô $22 \mathrm{~mm}$ long', $26 \mathrm{~mm}$ broad; length of lateral spine $9 \mathrm{~mm} ; 04^{\circ} 52^{\prime} 00 \mathrm{~m}, 135^{\circ} 25^{\prime} 00 \mathrm{~m}, 90 \mathrm{~m}$ deep, $28-v i-1964$.

\section{Genus Leucosia Fabricius.}

Leucosia longifrons de Haan

(Plate 3, figure B, C and D). 
leucosia urania, Bell, 1855, p.283; de Man, 1888,p.197, Leucosia longifrons, Bell, 1855, p.284; Alcock, 1896,p.217; Balss, 1922, p.128; Sakai, 1937, p.142, pl. XV, fig, l.

The descriptions of ALCOCK (1896) and SAKAI (1937) fit our specimens. But there is a row of brown hairs along the border of each ischium continuous halfway to each merus of the external maxilliped, in our two female specimens. This is not mentioned by both authors. SAKAI (1937), however, in the description of his new species, L. formosensis Sakai, mentions the above character besides the presence of tubercle or tooth on each, ischium which is mentioned also by ALCOCK (1896),

In many aspects our female specimens agree with $L$. formosensis sakai, especially that of the granulation. But the front, the distal portion of the arm (as represented in plate XV, fig.2 and not in text-fig. 27) and the coloration are different.

SAKAI (1937) compares the species with L.haswelli, Miers, but it is believed that L.formosensis is clocer to L. longifrons. Unfortunately his type specimen is female and there has been no other confirmation of SAKAI. (1937) to strengthen his new species. Dimorphism and form variation in L.longifrons may be responsible for Sakai's new species.

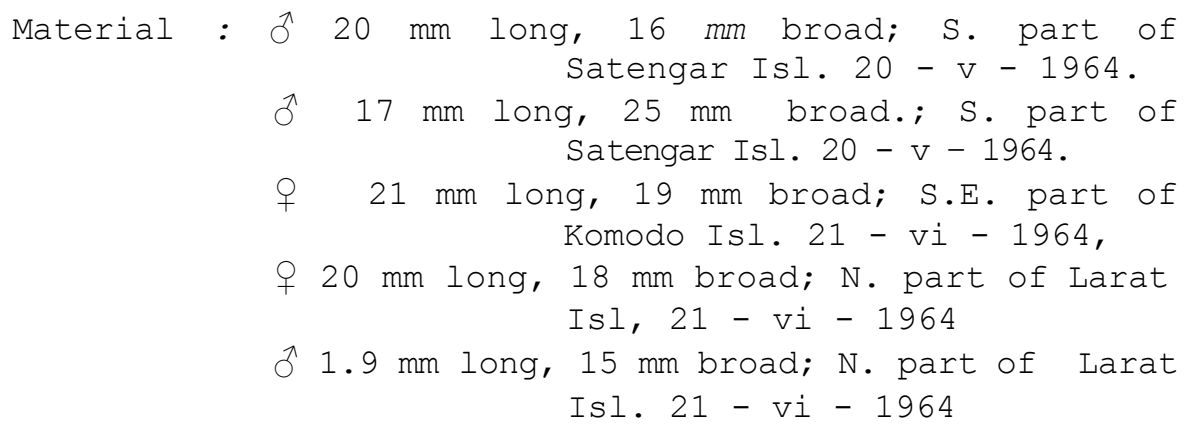




\section{ACKNOWLEDGMENT}

My sincere gratitude to :

Dr Raoul Serene, UNESCO expert for South East Asia, for his time spent to Identify provisionally our numerous specimens during his stay in Indonesia; Dr Gatot Rahardjo, director of the Institute of Marine Research, Djakarta, Indonesia, for facilities to publish this paper.

Prof. Dr A.J. Kosterman, Biologist of the Herbarium Bogoriense, for reviewing the manuscript. 


\section{BIBLIOGRAPHY}

Alcock, A. 1896.- Materials for a Carcinological Fauna of India. No. 2.

The Brachyura Oxystomata.- J. Asiat. Soc., Bengal.63, II, pp.134 - 296, pls. VI - VIII.

Balss, H. 1922.- Ostasiatische Decapoden III, Die DroMiaceen, Oxystomata und Parthenopi- den.Arch. f. Naturg. 88, Abt. A. Heft 3, pp.104 - 140, 9 figs,

Barnard, K.H. 1950.- Descriptive catalogue of South African Decapoda Crustacea (Crabs and Shrimps). Ann, South Afr. Mus.38, pp.345 - 400, 4 text-figs.

Bell, T. 1855.- Horae Carcinologicae or Notices of Crustacea. I. A Monograph of the Leu-cosiidae.Trans. Linn. Soc. London, Suppl. (I), 21, pp. $277-314$, pls, 30-

luitendijk, 34.
A. M.
$1939,-$
Results of the Snellius
Biological Expedition. $V$, The Dromiacea, Oxystomata and Oxyrhyncha of the Snellius Expedition.- Terminckia 4, pp.228 - 276, 24 figs., pIs.VII-XI.

?lman,W.T. 1926,- Zoological Results of the Cambridge Expedition to the Suez Canal 1924. XIII. Report on the Crustacea Decapoda (Brachyura).- Trans. Zool. Soc. London 22, pp.211- 217 .

?opra, B. 1933.- Further Notes on Crustacea Decapoda in the Indian Museum. III, On the Decapoda Crustacea collected by the Bengal Pilot Service off the Mouth of the River Hugli. Dromiacea and Oxystomata.-Rec. Ind. Mus. 35, I, pp.25-52, text-figs. 1-7.

?est, J. \& D. Guinot 1961,- Expedition francaise sur les Recifs coralliens de la Nouvelle- 
Caledonie. Crustaces Decapodes Brachyoures de Tahiti et des Tuamotu, Paris, $195 \mathrm{pp} .178$ figs, $18 \mathrm{pls}$.

Gordon, I. 1934.- Resultats Scientifiques des Voyages aux Indes Orientates Neerlandaises de L.L. A.A. R.R. le Prince at la Princesses Leopold de Belgique. Crustacea Brachyura.-

Mem. Mus. Roy. Nat. Belgiaue 3, Fasc. 18, 78 pp. 37 figs.

Ihle, J. E. W. 1916.- Die Decapoda Brachyura der SibogaExpedition, II, Oxystomata : Dorippidae.- Siboga Expedition, Monographie $39 b^{2}, 164$ pp., figs. $78-148$.

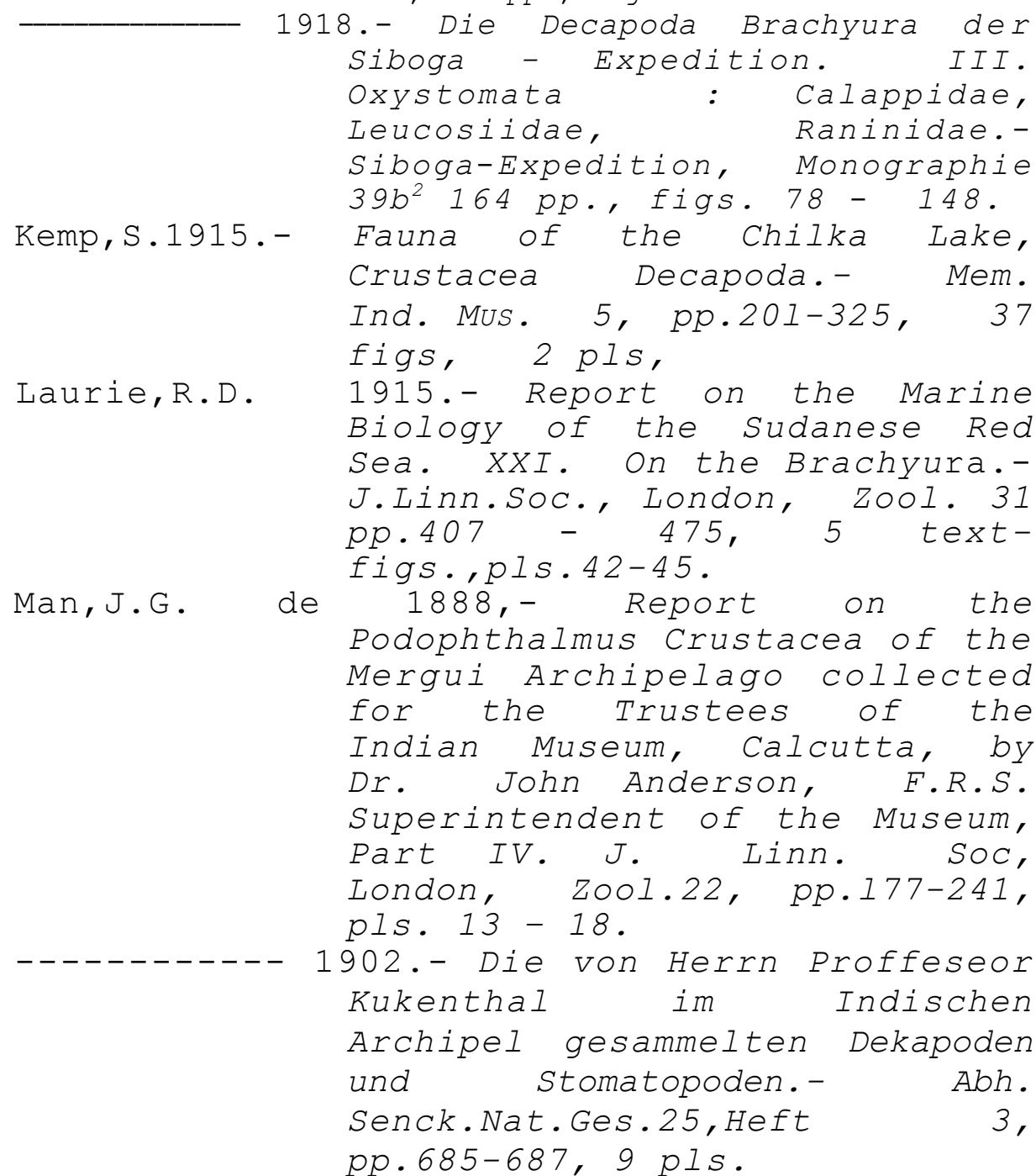


Miers, E. J. 1876.- Notes upon the Oxystomatous Crustacea.Trans. Linn. Soc., London, Zool. (2), 1 , Part 5, pp.235-249, pls. 38-40.

---------- 1880.- On a collection of Crustacea from the Malaysian Region. Part II. Telphusidea, Cetometopa and Oxystomata. Ann. \& Mag. Nat. Hist. 5, pp.3l5-317, pl. XIV, fig. 5 .

1884.- On some Crustaceans from Mauritius.Proc, Zoo., Soc., London (10),p. 13 .,

Rathbun, M.J. 1911.- The Percy Sladen Trust Expedition to the Indian Qcean in 1905, 3,no.11, Marine Brachyura.- Trans, Linn. Soc., London, Zool. (2), 14, Part 2, pp.191-260, 2 text-figs, pls. $X V-X X$.

Sakai, T. 1937.- Studies on the Crabs of Japan, II. Oxystomata.- Sci. Rep. Tokyo Bun. Daigaku, Sect. B. Suppl. No.2, pp.67-192, 45 text-fig., pls., pls.X-XIX.

Serene, R. 1954.- Sur quelques especes rares de Brachyuras (Leucosiidae) de l'Indo - Pacifique.Treubia 22, Part 3, pp.453 - 499, 7 figs., pls. 7 - 10.

1955.- $\quad$ Sur quelques especes rares de Brachyures (Leucosiidae) de l'Indo - Pacifique (2e Partie).- Treubia 23, Part 1, pp.137 248, 11 figs., pls. $6-11$.

Shen, C.J. 1931.- The Crabs of Hongkong Part II.- The Hongkong Naturalist 2, No.3, pp.185 197, 13 figs.,pls. $12-14$.

The Brachyuran Crustacea of North China.- Zool. Sin., Peiping, Ser.A. Fasc. 1. vol. 9, $321 \mathrm{pp} .171$ figs., 10 pls. 
Stebbing, T. R. R. 1908.- South African Crustacea.Mus. Ind, South Afr. 4, Part 3, pp. 21 - l23, 38 figs., pls. XVII - XXVI. 